\title{
Effects of platycodins on liver complications of type 2 diabetes
}

\author{
HAIYAN LUAN, LIMIN YANG, LEI LIU, SHUANG LIU, XIAOLIAN ZHAO, \\ HONGYU SUI, JINGTAO WANG and SHUQIU WANG
}

\begin{abstract}
Department of Basic Medical Sciences, Jiamusi University, Jiamusi, Heilongjiang 154007, P.R. China
\end{abstract}
Received November 30, 2013; Accepted January 23, 2014

DOI: $10.3892 / \mathrm{mmr} .2014 .2363$

\begin{abstract}
The aim of the current study was to investigate the therapeutic effects and mechanism of platycodin in liver complications of type 2 diabetes. All rats were randomly divided into two groups: The control group (normal diet) and the model group (a high-fat and high-sugar diet). The model group was injected with $2 \%$ streptozocin $(25 \mathrm{mg} / \mathrm{kg}$ body weight) through the tail vein following 4 weeks of dieting. After a total of 8 weeks of dieting, fasting blood glucose (FBG) and liver function were examined. The high-fat and high-sugar diet was continued in the successful model rats, which were randomly divided into four groups and treated with the following doses of platycodins: The untreated, and 50,100 and $200 \mathrm{mg} / \mathrm{kg}$ body weight/day groups. Platycodins treatment lasted for 12 weeks. Platycodins treatment at a dose of $200 \mathrm{mg} / \mathrm{kg}$ body weight/day reduced the FBG, glutamate pyruvate transaminase (GPT), glutamic oxalacetic transaminase, triglycerides, total cholesterol (TC), low-density lipoprotein (LDL) and liver index levels compared with the untreated group $(\mathrm{P}<0.05)$, while the high-density lipoprotein levels increased $(\mathrm{P}<0.05)$. Furthermore, FBG, GPT, TC and LDL levels were returned to the normal level. This dose also increased the expression of BMP-9 mRNA and BMP-9 protein, and reduced the expression of Smad-4 mRNA and Smad-4 protein. These findings indicate that platycodins can rectify disorders of blood glucose and lipid metabolism, improve liver index and protect liver function in liver complications of type 2 diabetes. The current study suggests that this therapeutic effect is mediated through the BMP-9/Smad-4 pathway.
\end{abstract}

\section{Introduction}

Diabetes mellitus (DM) is a metabolic disorder characterized by chronic hyperglycemia. While several causative factors have been attributed to DM, pathogenesis of the disease is complex and is not yet entirely understood. DM is becoming

Correspondence to: Professor Shuqiu Wang, Department of Basic Medical Sciences, Jiamusi University, 148 Universities Street, Jiamusi, Heilongjiang 154007, P.R. China

E-mail: wang_shuqiu@163.com

Key words: platycodins, type 2 diabetes, liver complications, BMP-9/Smad-4 pathway increasingly prevalent, which may be due to changes in lifestyle, an aging population and improved means of diagnostic detection (1). Type 2 diabetes can lead to complications of the liver (the organ commonly affected by long-term hyperglycemia) in addition to the kidneys, heart, retina and nervous system (2-5). It has been reported that $21-78 \%$ of patients with DM have fatty livers, and certain serious cases develop into liver fibrosis (6). Therefore, the liver complications of type 2 diabetes have become a key problem that requires a solution.

Bone morphogenetic protein-9 (BMP-9), also termed growth differentiation factor 2 , is a member of the transforming growth factor- $\beta$ (TGF- $\beta$ ) superfamily and is important in metabolism. BMP-9 was first isolated in the developing mouse liver (7). It was also demonstrated to be expressed in nonparenchymal adult neurons (8), liver cells (9) and bone cells (10). As the primary regulatory factors of glucose and lipid metabolism, BMPs exert their biological effects through a complex system of signal transduction pathways. BMPs bind to their specific receptor and interact with Smad proteins. Smad-4 is the only established common-mediator-Smad (co-Smad) in a plethora of mammalian cell types, and its role is unique within the Smad family. Smad-4 is not only an effector of TGF- $\beta$ signaling (11), but also functions as a co-Smad by heterodimerizing, entering the nucleus and helping to activate transcription (12-15). Therefore, its biological functions are regulated, in part, by its interactions with other Smads or signaling proteins.

Platycodon grandiflorus is an edible root that has been used for its medicinal properties. The root of this plant contains high levels of pharmacologically active triterpenoid saponins (16-20), which have been indicated to have hepatoprotective properties. However, it is not clear whether the BMP-9/Smad-4 pathway is involved in this hepatoprotective mechanism. In the current study, it was determined whether the BMP-9/Smad-4 pathway was involved in the effect of platycodins. Clarification of the effective mechanism of platycodins in glucolipid metabolic pathways may elucidate a potential therapeutic agent for treating liver complications that arise from type 2 diabetes.

\section{Materials and methods}

Chemicals. Platycodins were obtained from Xi'an Guanyu Bio-Tech Co., Ltd. (Xi'an, China). Streptozocin (STZ) was obtained from Sigma-Aldrich (St. Louis, MO, USA). Molecular biology reagents and kits for measuring fasting 
blood glucose (FBG), triglycerides (TG), total cholesterol (TC), high-density lipoprotein (HDL), low-density lipoprotein (LDL), glutamate pyruvate transaminase (GPT) and glutamic oxalacetic transaminase (GOT) were obtained from Nanjing KGI Biological Technology Development Co., Ltd. (Nanjing, China). Antibodies against BMP-9, Smad-4 and $\beta$-actin were obtained from Santa Cruz Biotechnology (Santa Cruz, CA, USA). A Fermentas protein ladder was obtained from Thermo Fisher Scientific (Pittsburgh, PA, USA).

Animals and treatment. Thirty pathogen-free Sprague-Dawley rats (180-220 g, Animal Center of Jiamusi University, Jiamusi, China) were provided standard rat chow and tap water ad libitum. The study was approved by the ethics committee of Jiamusi University. All rats were randomly divided into two groups: The control group (normal diet, $n=5$ ) and the model group (diabetes and liver complications, $n=25$ ). To produce animal models of diabetes with liver complications, the rats in the model group were fed a high-fat and -sugar diet for 8 weeks, with injection of $2 \%$ STZ $(25 \mathrm{mg} / \mathrm{kg}$ body weight) through the tail vein at week 4 . The rats in the control group were fed a normal diet containing corn, soybeans, wheat bran and fish meal. The rats in the model group were fed the normal diet supplemented with $10 \%$ sucrose, $15 \%$ lard, $2 \%$ cholesterol, and $0.25 \%$ bile acid. After 8 weeks, the FBG and liver function of the models were examined. The rats with FBG $\geq 16.8 \mathrm{mmol} / \mathrm{l}$ and abnormal liver function were included in the model group $(21,22)$. Twenty successful model rats were produced, and were continued on the high-fat and -sugar diet, then randomly divided into four groups ( $n=5$ in each group) that were treated with the following doses of platycodins: The untreated controls, and the 50, 100 and $200 \mathrm{mg} / \mathrm{kg}$ body weight/day groups. The control group was maintained with a normal diet. The control and untreated groups were treated with distilled water, while the 50, 100 and $200 \mathrm{mg} / \mathrm{kg}$ body weight/day groups were intragastrically administered with the corresponding concentrations of platycodins dissolved in aqueous solution. Platycodins treatment lasted for 12 weeks. After the 12-week treatment, the rats fasted for $12 \mathrm{~h}$, then were anesthetized by pentobarbital $(0.1 \mathrm{mg} / \mathrm{g}$ body weight $)$ and sacrificed by cervical dislocation. The blood was collected and livers were resected to be used for subsequent analysis.

\section{Detection contents}

Liver index. The weights of the bodies and livers of the rats were recorded and then used to calculate the liver index according to the following formula: Liver index $=$ liver weight/body weight.

FBG, blood lipids and liver function. An automatic biochemical analyzer (Olympus, Osaka, Japan) was used to detect FBG, the levels of blood lipids (TG, TC, LDL and HDL) and the liver function (GPT and GOT).

Reverse transcription-polymerase chain reaction (RT-PCR). Total RNA was purified from liver tissue using the Protein \& RNA Extraction kit for Mammalian Cells (Takara Biotechnology, Dalian, China). RNA was quantified using spectrophotometry (Beckman Coulter, CA, USA) and reverse-transcribed to cDNA. cDNA was amplified using a master mix containing LA Taq DNA Polymerase (Takara Biotechnology). The following primer sequences were used (Augct DNA-Syn Biotechnology Co., Ltd., Beijing, China): Sense: 5'-GGGACCAAGGAGACCAGACTG-3' and antisense: 5'-CGCCCATGTCATCCTTGTAGA-3' for BMP-9; sense: 5'-TAAAGGTGAAGGGGACGTGTG-3' and antisense: 5'-CATGGTGTGCAGGACTTCATC-3' for Smad-4; and sense: 5'-TCCTCCCTGGAGAAGAGCTA-3' and antisense: 5'-TCAGGAGGAGCAATGATCTTG-3' for $\beta$-actin. The final concentration of each primer was $20 \mu \mathrm{M}$. The PCR products were separated on a $1.5 \%$ agarose gel and stained with ethidium bromide to identify fragments of BMP-9, Smad-4 and $\beta$-actin. The reaction conditions were as follows: $94^{\circ} \mathrm{C}$ for $5 \mathrm{~min}$, denaturation at $94^{\circ} \mathrm{C}$ for $30 \mathrm{sec}$, annealing at $56^{\circ} \mathrm{C}$ for $45 \mathrm{sec}$, extension 25 cycles at $72^{\circ} \mathrm{C}$ for $1 \mathrm{~min}$, followed by a final step at $72^{\circ} \mathrm{C}$ for $10 \mathrm{~min}$ for $\beta$-actin, fragment length $357 \mathrm{bp}$; $94^{\circ} \mathrm{C}$ for $5 \mathrm{~min}$, denaturation at $94^{\circ} \mathrm{C}$ for $30 \mathrm{sec}$, annealing at $64^{\circ} \mathrm{C}$ for $45 \mathrm{sec}$, extension 31 cycles at $72^{\circ} \mathrm{C}$ for $1 \mathrm{~min}$, followed by a final step at $72^{\circ} \mathrm{C}$ for $10 \mathrm{~min}$ for $B M P-9$, fragment length $427 \mathrm{bp}$; and $94^{\circ} \mathrm{C}$ for $5 \mathrm{~min}$, denaturation at $94^{\circ} \mathrm{C}$ for $30 \mathrm{sec}$, annealing at $60^{\circ} \mathrm{C}$ for $45 \mathrm{sec}$, extension 33 cycles at $72^{\circ} \mathrm{C}$ for $1 \mathrm{~min}$, followed by a final step at $72^{\circ} \mathrm{C}$ for $10 \mathrm{~min}$ for Smad -4 , fragment length $357 \mathrm{bp}$.

Western blot analysis. Protein samples from liver tissues were separated using $10 \%$ sodium dodecyl sulfate-polyacrylamide gel electrophoresis and transferred to nitrocellulose membranes (Pall Life Sciences, Port Washington, NY, USA). Membranes were blocked with 5\% non-fat dry milk in $0.1 \%$ Tris-buffered saline with Tween-20 (TBST, Sigma-Aldrich), and then washed with $0.1 \%$ TBST. The membranes were incubated with the primary antibodies overnight at $4^{\circ} \mathrm{C}$. After four 10 -min washes with $0.1 \%$ TBST, the membranes were incubated with horseradish peroxidase-conjugated AffiniPure goat anti-rabbit secondary antibody (Zsgb-Bio, Beijing, China) for $1 \mathrm{~h}$. SuperSignal West Pico Chemiluminescent Substrate (Pierce Biotechnology, Inc., Rockford, IL, USA) was used to detect the protein bands. Protein band intensities were quantified by densitometry using Quantity One software (Bio-Rad Laboratories, Hercules, CA, USA).

Statistical analysis. Data are presented as the mean \pm standard deviation. Student's t-tests were utilized to analyze differences between groups. $\mathrm{P}<0.05$ was considered to indicate a statistically significant difference.

\section{Results}

FBG levels in rat models of type 2 diabetes with liver complications. Rats in the $200 \mathrm{mg} / \mathrm{kg}$ body weight/day group exhibited reduced FBG levels compared with the untreated group $(\mathrm{P}<0.05)$; the FBG levels were reduced to the level of the healthy control mice. No changes were observed in the 50 and $100 \mathrm{mg} / \mathrm{kg}$ body weight/day groups compared with the untreated group (Table I).

GPT and GOT levels. As markers of liver health, elevated levels of GPT and GOT in the serum signify a disease state. Compared with the untreated group, GPT and GOT levels in the $200 \mathrm{mg} / \mathrm{kg}$ body weight/day group were significantly 
Table I. Levels of FBG, GPT, GOT and liver index in each group.

\begin{tabular}{lcccc}
\hline Group & FBG (mmo1/l) & GPT (mmo1/l) & GOT (mmo1/l) & Liver index \\
\hline Control & $7.784 \pm 0.591$ & $68.088 \pm 1.942$ & $98.360 \pm 1.467$ & $0.022 \pm 0.001$ \\
Untreated & $21.704 \pm 0.423^{\mathrm{a}}$ & $129.638 \pm 3.240^{\mathrm{a}}$ & $282.966 \pm 4.039^{\mathrm{a}}$ & $0.044 \pm 0.006^{\mathrm{a}}$ \\
$50 \mathrm{mg} / \mathrm{kg} /$ day & $21.082 \pm 0.492^{\mathrm{a}}$ & $126.154 \pm 1.558^{\mathrm{a}}$ & $279.798 \pm 1.494^{\mathrm{a}}$ & $0.041 \pm 0.004^{\mathrm{a}}$ \\
$100 \mathrm{mg} / \mathrm{kg} /$ day & $20.302 \pm 1.122^{\mathrm{a}}$ & $121.312 \pm 5.774^{\mathrm{a}}$ & $272.086 \pm 7.743^{\mathrm{a}}$ & $0.039 \pm 0.005^{\mathrm{a}}$ \\
$200 \mathrm{mg} / \mathrm{kg} /$ day & $8.488 \pm 0.369^{\mathrm{b}}$ & $71.944 \pm 2.245^{\mathrm{b}}$ & $191.448 \pm 2.566^{\mathrm{a}, \mathrm{b}}$ & $0.027 \pm 0.003^{\mathrm{a}, \mathrm{b}}$ \\
\hline
\end{tabular}

Data are presented as the mean \pm standard deviation, $n=5$. ${ }^{\mathrm{a}} \mathrm{P}<0.05$ vs. the control group and ${ }^{\mathrm{b}} \mathrm{P}<0.05$ vs. the untreated group. FBG, fasting blood glucose; GPT, glutamate pyruvate transaminase; GOT, glutamic oxalacetic transaminase.

Table II. Blood lipid levels in each group.

\begin{tabular}{lllll}
\hline Group & TG $(\mathrm{mmo1} / \mathrm{l})$ & TC $(\mathrm{mmo1} / \mathrm{l})$ & LDL $(\mathrm{mmo1} / \mathrm{l})$ & $\mathrm{HDL}(\mathrm{mmo} 1 / \mathrm{l})$ \\
\hline Control & $0.798 \pm 0.037$ & $1.784 \pm 0.043$ & $0.216 \pm 0.015$ & $2.956 \pm 0.031$ \\
Untreated & $2.898 \pm 0.065^{\mathrm{a}}$ & $4.480 \pm 0.045^{\mathrm{a}}$ & $0.856 \pm 0.028^{\mathrm{a}}$ & $1.414 \pm 0.032^{\mathrm{a}}$ \\
$50 \mathrm{mg} / \mathrm{kg} /$ day & $2.792 \pm 0.105^{\mathrm{a}}$ & $4.440 \pm 0.039^{\mathrm{a}}$ & $0.824 \pm 0.036^{\mathrm{a}}$ & $1.448 \pm 0.026^{\mathrm{a}}$ \\
$100 \mathrm{mg} / \mathrm{kg} /$ day & $2.730 \pm 0.132^{\mathrm{a}}$ & $4.406 \pm 0.059^{\mathrm{a}}$ & $0.810 \pm 0.032^{\mathrm{a}}$ & $1.490 \pm 0.067^{\mathrm{a}}$ \\
$200 \mathrm{mg} / \mathrm{kg} /$ day & $0.898 \pm 0.070^{\mathrm{a}, \mathrm{b}}$ & $1.988 \pm 0.208^{\mathrm{b}}$ & $0.234 \pm 0.019^{\mathrm{b}}$ & $2.868 \pm 0.040^{\mathrm{a}, \mathrm{b}}$ \\
\hline
\end{tabular}

Data are presented as the mean \pm standard deviation, $\mathrm{n}=5$. ${ }^{\mathrm{a}} \mathrm{P}<0.05$ vs. the control group, ${ }^{\mathrm{b}} \mathrm{P}<0.05$ vs. the untreated group. TG, triglyceride; TC, total cholesterol; LDL, low-density lipoprotein; HDL, high-density lipoprotein.

reduced $(\mathrm{P}<0.05)$, and GPT levels were reduced to the level of the controls. No changes in GPT and GOT levels were detected in the 50 and $100 \mathrm{mg} / \mathrm{kg}$ body weight/day groups compared with the untreated model group (Table I).

Liver index following treatment with platycodins. Compared with the untreated group, the liver index of the $200 \mathrm{mg} / \mathrm{kg}$ body weight/day group was reduced, but remained significantly higher than the healthy control group $(\mathrm{P}<0.05)$, indicating that platycodins treatment significantly reduces the liver size of rat models of diabetes with liver complications. No changes were observed in the 50 and $100 \mathrm{mg} / \mathrm{kg}$ body weight/day groups compared with the untreated group (Table I).

Effects of platycodins on lipid regulation. Compared with the untreated group, TG, TC and LDL levels in the $200 \mathrm{mg} / \mathrm{kg}$ body weight/day group were significantly reduced $(\mathrm{P}<0.05)$, while the HDL levels significantly increased $(\mathrm{P}<0.05)$. The levels of TC and LDL detected in the $200 \mathrm{mg} / \mathrm{kg}$ body weight/day group were close to levels in the control group, suggesting that $200 \mathrm{mg} / \mathrm{kg}$ body weight platycodins successfully returned the levels of TC and LDL to healthy levels. Consistent with the data regarding FBG and liver health, no changes were detected when rats were treated with $<200 \mathrm{mg} / \mathrm{kg}$ body weight platycodins (Table II).

Changes in BMP-9 and Smad-4 expression following treatment with platycodins. The aforementioned results suggest that treatment with $200 \mathrm{mg} / \mathrm{kg}$ body weight platycodins rectifies liver complications and glucolipid regulation in rats with type 2 diabetes. Since the BMP-9 and Smad-4 signaling pathway is crucial to lipid and glucose metabolism, the effects of platycodins on these proteins was investigated. Total RNA was isolated from liver tissue and mRNA levels were detected by RT-PCR. BMP-9 mRNA expression levels were reduced (Fig. 1), while those of Smad-4 were increased (Fig. 2) in the model rats compared with healthy control rats. Notably, treatment with $200 \mathrm{mg} / \mathrm{kg}$ body weight platycodins significantly upregulated the expression of BMP-9 and downregulated the expression of Smad-4 $(\mathrm{P}<0.05$ vs. untreated models) to levels that were not significantly higher than those of healthy control rats (Figs. 1 and 2).

To confirm that protein levels of BMP-9 and Smad-4 followed the same pattern as the mRNA levels, proteins were extracted from liver tissues and western blot analysis was performed. Consistent with mRNA expression patterns, BMP-9 expression increased following treatment with $200 \mathrm{mg} / \mathrm{kg}$ body weight platycodins (Fig. 3). Similarly, Smad-4 expression was reduced to the level of the healthy controls (Fig. 4).

\section{Discussion}

The findings of the present study demonstrate that treatment with $200 \mathrm{mg} / \mathrm{kg}$ body weight platycodins can rectify disorders of blood glucose and lipid metabolism in rat models of type 2 diabetes with liver complications, by improving liver index and protecting liver function. Furthermore, it was demonstrated that the therapeutic effect of $200 \mathrm{mg} / \mathrm{kg}$ body weight platycodins was mediated through the BMP-9/Smad-4 pathway. This was supported by the observation that platycodins increased BMP-9 and reduced Smad-4 expression. 

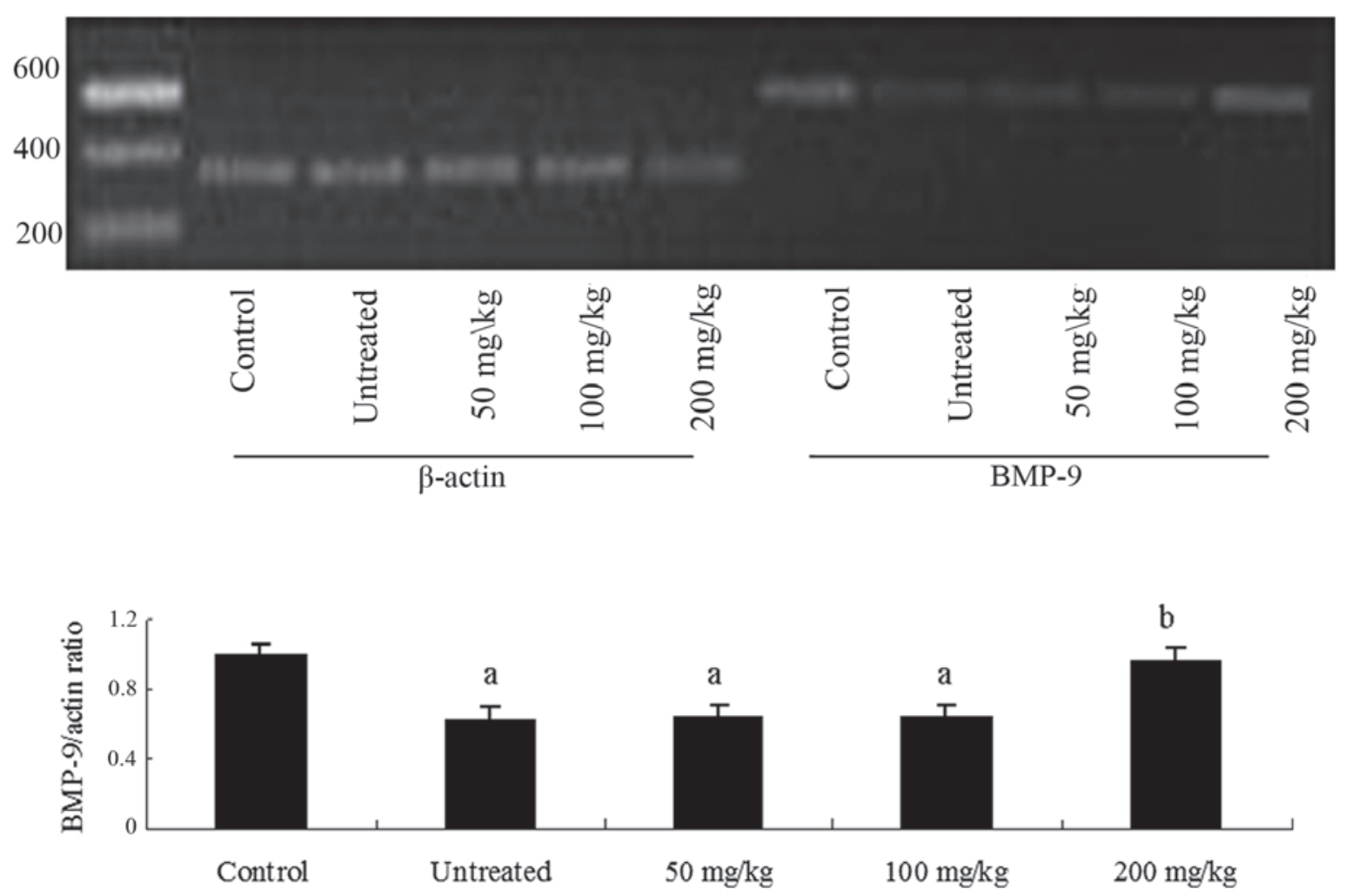

Figure 1. Effect of platycodins on BMP-9 mRNA expression. $\beta$-actin was used as a positive control. Ethidium bromide was used to observe the polymerase chain reaction products for $B M P-9(427 \mathrm{bp})$ and $\beta$ - $\operatorname{actin}(357 \mathrm{bp})$. Data are presented as the mean \pm standard deviation, $\mathrm{n}=5$. ${ }^{\mathrm{a}} \mathrm{P}<0.05 \mathrm{vs}$. the control group, ${ }^{\mathrm{b}} \mathrm{P}<0.05$ vs. the untreated group.
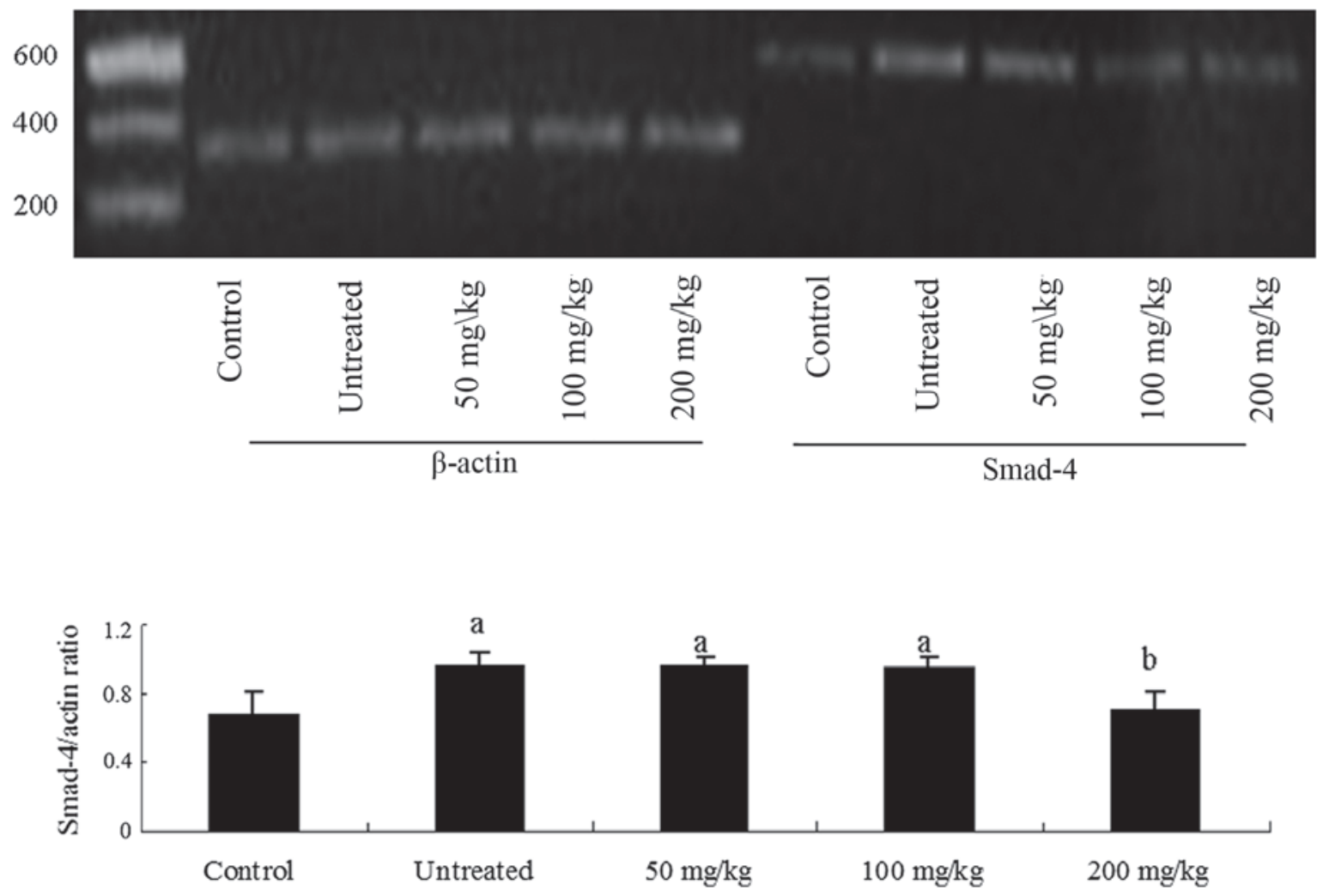

Figure 2. Effect of platycodins on Smad-4 mRNA expression. $\beta$-actin was used as a positive control. Ethidium bromide was used to observe the polymerase chain reaction products for Smad-4 (436 bp) and $\beta$-actin ( $357 \mathrm{bp})$. Data are presented as the mean \pm standard deviation, $\mathrm{n}=5$. ${ }^{\mathrm{a}} \mathrm{P}<0.05 \mathrm{vs}$. the control group, ${ }^{\mathrm{b}} \mathrm{P}<0.05$ vs. the untreated group. 

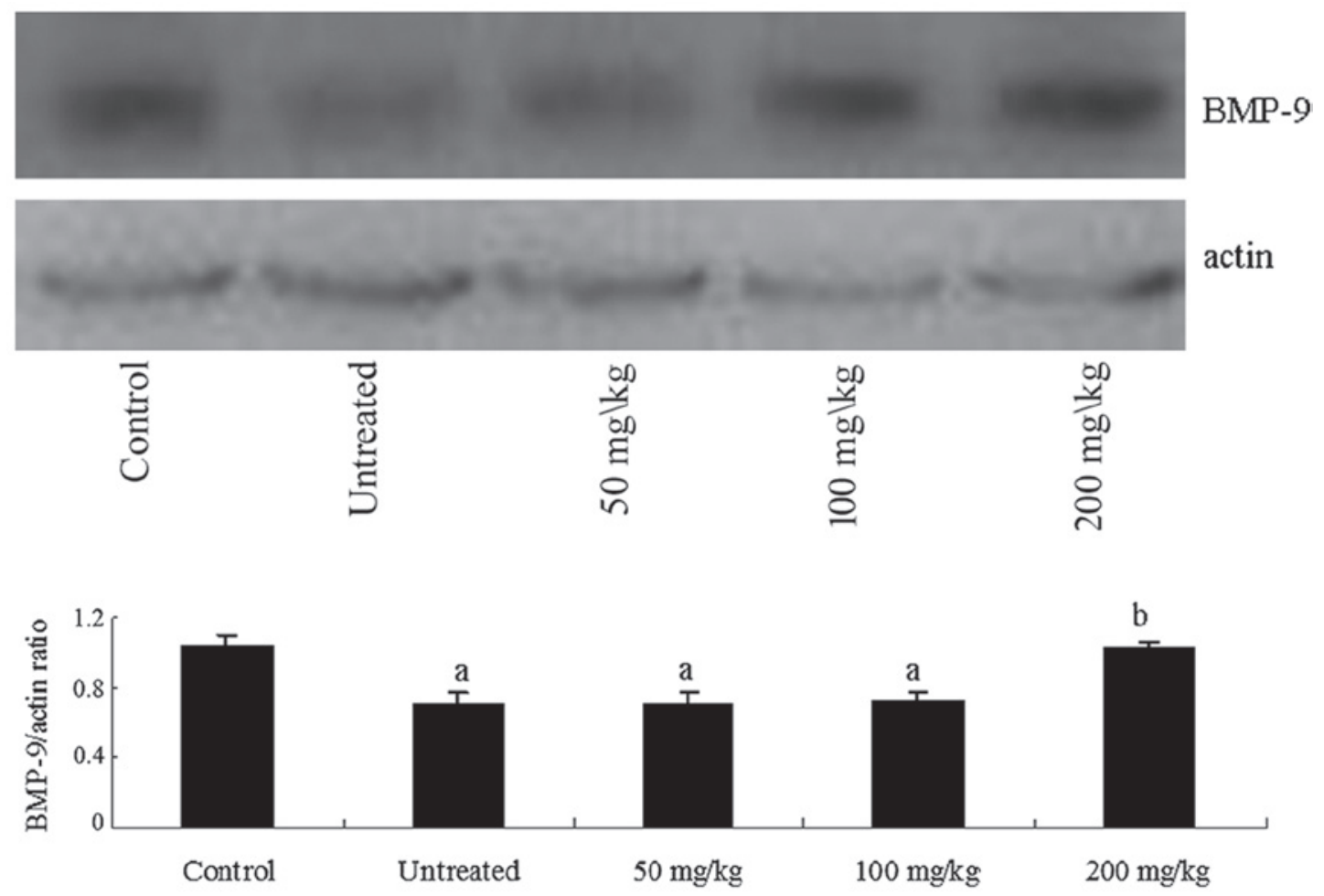

Figure 3. Effect of platycodins on BMP-9 protein expression as detected by western blot analysis. Data are presented as the mean \pm standard deviation, $\mathrm{n}=5$. ${ }^{\mathrm{a}} \mathrm{P}<0.05$ vs. the control group, ${ }^{\mathrm{b}} \mathrm{P}<0.05$ vs. the untreated group.
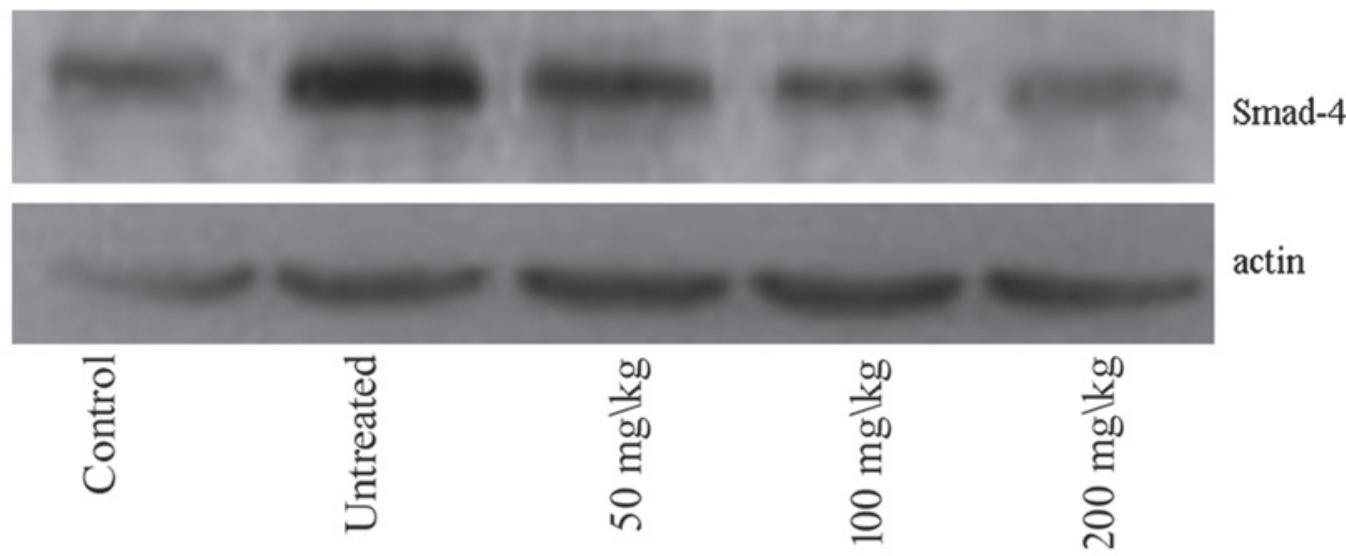

actin

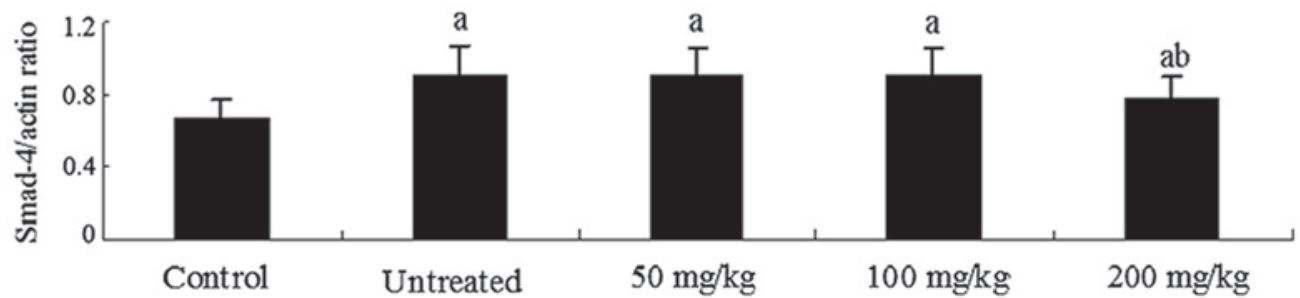

Figure 4. Effect of platycodins on Smad-4 protein expression as detected by western blot. Data are presented as the mean \pm standard deviation, $\mathrm{n}=5$. ${ }^{\mathrm{a}} \mathrm{P}<0.05$ vs. the control group, ${ }^{\mathrm{b}} \mathrm{P}<0.05$ vs. the untreated group.

Chronic high blood glucose is a serious factor contributing to complications in type 2 diabetes. Persistent hyperglycemia can result in liver damage, aggravate lipid metabolism disorder, alter the structure of liver and compromise liver function.
In addition, patients with diabetes usually have microvascular and microcirculation complications that can result in ischemia and hypoxia in other organs. Ischemia can cause carbon dioxide accumulation, acidosis, oxygen deficiency and 
bilirubin metabolism disorders. Ischemia can also reduce the phosphorylation capacity and increase the activity of GPT and GOT in liver cells. Platycodins have been indicated to improve liver function and alleviate the hepatotoxicity caused by tert-butyl hydroperoxide (23), acetaminophen activation (24), carbon tetrachloride (25) and cholestasis (26). They can reduce the serum levels of alanine aminotransferase and aspartate aminotransferase, scavenge oxygen free radicals and protect cells from oxidative stress (23). Furthermore, it can inhibit P450-mediated acetaminophen bioactivation (24). In addition to the hepatoprotection, platycodon root is involved in the modulation of glucose and lipid metabolisms. Previous studies demonstrated that platycodin $\mathrm{D}$ regulates adipogenesis via the Wnt/ $\beta$-catenin (27) and AMPK-dependent signaling pathways (28). In another study, it ameliorated obesity and insulin resistance in obese mice via the activation of the AMPK/ACC pathways, and also reduced adipocyte differentiation (29). It has been reported that Platycodon grandiflorum extract ameliorated obesity in mice fed a high fiber diet and increased glucose uptake in L6 muscle cells by modifying adipokines, which indicates clinical benefits of platycodon as a supplement to treat obesity and diabetes (30). It has also been indicated that platycodins promote pancreatic exocrine activity and improve the function of the pancreas by promoting the release of cholecystokinin (31). Platycodins significantly reduced cholesterol (32) and postprandial glucose concentration by increasing insulin and glucose transporter protein-4 expression levels in the plasma of obese and lean Zucker rats (33). Other studies have also confirmed that platycodins can inhibit pancreatic lipase activity and reduce lipid content of the plasma and liver in a dose-dependent manner (26,30,34).

As a potential autocrine/paracrine mediator in the hepatic reticuloendothelial system (9), BMP-9 has been implicated in recent studies in the regulation of glucose and lipid metabolism (35). BMP-9 has insulin-like regulatory functions in glucose metabolism. It promotes insulin secretion of pancreatic $\beta$ cells and glycogen synthesis in muscle cells, while it suppresses gluconeogenesis in the liver (36). These processes act synergistically to reduce blood glucose levels. Additionally, BMP-9 is important in liver regeneration and has an antifibrotic function in liver $(37,38)$. In addition to its roles in glucose metabolism and liver health, BMP-9 is also involved in lipid metabolism. It stimulates the synthesis of malic enzyme and fatty acid synthase, which are key enzymes in the hepatic fatty acid metabolism pathway $(36,39)$. BMP-9 functions similarly to leptin (39) and opposite to resistin and resistin-like proteins (40). As a glucose and lipid metabolism regulatory factor, BMP-9 may have far-reaching roles in the development and treatment of diabetes, and it has previously been proposed as a candidate for the hepatic insulin-sensitizing substance (HISS) (41). BMPs function by binding to specific receptors and interacting with Smad proteins. Smad-4 is the only established co-Smad in mammals, and its role is unique within the Smad family. Smad-4 dysfunction has been implicated in liver fibrosis. Experiments using a cirrhotic mouse model indicated that the downregulation of Smad-4 expression by RNA interference leads to a reduction in the mRNA levels of TGF- $\beta 1$, type II collagen and matrix metalloproteinase inhibitor I. Furthermore, the protein levels of type I collagen were reduced. Together, these changes lead to improvements in liver function (42).
Overall, the data from the present study have indicated that the mechanism underlying the effects of platycodins in liver complications associated with type 2 diabetes involves the BMP-9/Smad-4 pathway. Notably, the present study is limited, since other regulatory pathways may be affected by platycodins and contribute to their therapeutic effects. Therefore, additional studies are required in order to examine its therapeutic potential in a clinical setting.

\section{Acknowledgements}

The current study was partially supported by the grant from the Chinese Heilongjiang Provincial Health Department Science Foundation (grant no. 2011-429) and Chinese Heilongjiang Province Pharmaceutical Administration Science Foundation (grant no. ZHY12-W043).

\section{References}

1. Gujral UP, Pradeepa R, Weber MB, Narayan KM and Mohan V: Type 2 diabetes in South Asians: similarities and differences with white Caucasian and other populations. Ann NY Acad Sci 1281: 51-63, 2013.

2. Börgeson E and Godson C: Resolution of inflammation: therapeutic potential of pro-resolving lipids in type 2 diabetes mellitus and associated renal complications. Front Immunol 3: 318, 2012.

3. Uslu S, Kebapçi N, Kara M and Bal C: Relationship between adipocytokines and cardiovascular risk factors in patients with type 2 diabetes mellitus. Exp Ther Med 4: 113-120, 2012.

4. Sen S, Chen S, Feng B, Iglarz M and Chakrabarti S: Renal, retinal and cardiac changes in type 2 diabetes are attenuated by macitentan, a dual endothelin receptor antagonist. Life Sci 91: 658-668, 2012

5. Tovilla-Zárate C, Juárez-Rojop I, Peralta Jimenez Y, et al: Prevalence of anxiety and depression among outpatients with type 2 diabetes in the Mexican population. PLoS One 7: e36887, 2012.

6. Salas-Flores R, González-Pérez B and Echegollen-Guzmán A: Hepatic steatosis and type 2 diabetes mellitus in health workers. Rev Med Inst Mex Seguro Soc 50: 13-18, 2012.

7. Song JJ, Celeste AJ, Kong FM, et al: Bone morphogenetic protein-9 binds to liver cells and stimulates proliferation. Endocrinology 136: 4293-4297, 1995.

8. López-Coviella I, Berse B, Krauss R, Thies RS and Blusztajn JK: Induction and maintenance of the neuronal cholinergic phenotype in the central nervous system by BMP-9. Science 289: 313-316, 2000.

9. Miller AF, Harvey SA, Thies RS and Olson MS: Bone morphogenetic protein-9. An autocrine/paracrine cytokine in the liver. J Biol Chem 275: 17937-17945, 2000.

10. Suttapreyasri S, Koontongkaew S, Phongdara A and Leggat U: Expression of bone morphogenetic proteins in normal human intramembranous and endochondral bones. Int J Oral Maxillofac Surg 35: 444-452, 2006

11. Miyazono K: TGF-beta/SMAD signaling and its involvement in tumor progression. Biol Pharm Bull 23: 1125-1130, 2000.

12. Ten Dijke P, Goumans MJ, Itoh F and Itoh S: Regulation of cell proliferation by Smad proteins. J Cell Physiol 191: 1-16, 2002.

13. Feng XH and Derynck R: A kinase subdomain of transforming growth factor-beta (TGF-beta) type I receptor determines the TGF-beta intracellular signaling specificity. EMBO J 16: 3912-3923, 1997.

14. Bedossa P and Paradis V: Transforming growth factor-beta (TGF-beta): a key-role in liver fibrogenesis. J Hepatol 22 (Suppl): 37-42, 1995.

15. Attisano L and Wrana JL: Signal transduction by the TGF-beta superfamily. Science 296: 1646-1647, 2002.

16. Ma G, Guo W, Zhao L, et al: Two new triterpenoid saponins from the root of Platycodon grandiflorum. Chem Pharm Bull (Tokyo) 61: 101-104, 2013.

17. Fu WW, Fu JN, Zhang WM, et al: Platycoside O, a new triterpenoid saponin from the roots of Platycodon grandiflorum. Molecules 16: 4371-4378, 2011. 
18. Li W, Zhang W, Xiang L, et al: Platycoside N, a new oleanane-type triterpenoid saponin from the roots of Platycodon grandiflorum. Molecules 15: 8702-8708, 2010.

19. Choi YH, Yoo DS, Choi CW, et al: Platyconic acid A, a genuine triterpenoid saponin from the roots of Platycodon grandiflorum. Molecules 13: 2871-2879, 2008.

20. Fu WW, Shimizu N, Dou DQ, et al: Five new triterpenoid saponins from the roots of Platycodon grandiflorum. Chem Pharm Bull (Tokyo) 54: 557-560, 2006.

21. Hu A-M, Xiao F-Y and Zheng Y: Establishing and valuating animal model resembling to type two diabetes mellitus with intercurrent fatty liver. Chin J Int Trad Western Med Digestion 14: 156-159, 2006 (In Chinese)

22. Reed MJ, Meszaros K, Entes LJ, et al: A new rat model of type 2 diabetes: the fat-fed, streptozotocin-treated rat. Metabolism 49: $1390-1394,2000$

23. Lee KJ, Choi CY, Chung YC, et al: Protective effect of saponins derived from roots of Platycodon grandiflorum on tert-butyl hydroperoxide-induced oxidative hepatotoxicity. Toxicol Lett 147: 271-282, 2004

24. Lee KJ, You HJ, Park SJ, et al: Hepatoprotective effects of Platycodon grandiflorum on acetaminophen-induced liver damage in mice. Cancer Lett 174: 73-81, 2001.

25. Lee KJ and Jeong HG: Protective effect of Platycodi radix on carbon tetrachloride-induced hepatotoxicity. Food Chem Toxicol 40: 517-525, 2002.

26. Kim TW, Lee HK, Song IB, et al: Platycodin D attenuates bile duct ligation-induced hepatic injury and fibrosis in mice. Food Chem Toxicol 51: 364-369, 2013.

27. Lee H, Bae S, Kim YS and Yoon Y: WNT/ $\beta$-catenin pathway mediates the anti-adipogenic effect of platycodin D, a natural compound found in Platycodon grandiflorum. Life Sci 89 388-394, 2011.

28. Hwang YP, Choi JH, Kim HG, et al: Saponins, especially platycodin D, from Platycodon grandiflorum modulate hepatic lipogenesis in high-fat diet-fed rats and high glucose-exposed HepG2 cells. Toxicol Appl Pharmacol 267: 174-183, 2013.

29. Lee CE, Hur HJ, Hwang JT, et al: Long-term consumption of Platycodi radix ameliorates obesity and insulin resistance via the activation of AMPK pathways. Evid Based Complement Alternat Med 2012: 759143, 2012.

30. Ahn YM, Kim SK, Kang JS and Lee BC: Platycodon grandiflorum modifies adipokines and the glucose uptake in high-fat diet in mice and L6 muscle cells. J Pharm Pharmacol 64: 697-704, 2012.
31. Arai I, Komatsu Y, Hirai Y, et al: Stimulative effects of saponin from kikyo-to, a Japanese herbal medicine, on pancreatic exocrine secretion of conscious rats. Planta Med 63: 419-424, 1997.

32. Zhao HL, Harding SV, Marinangeli CP, Kim YS and Jones PJ: Hypocholesterolemic and anti-obesity effects of saponins from Platycodon grandiflorum in hamsters fed atherogenic diets. J Food Sci 73: H195-H200, 2008

33. Kim KS, Seo EK, Lee YC, et al: Effect of dietary Platycodon grandiflorum on the improvement of insulin resistance in obese Zucker rats. J Nutr Biochem 11: 420-424, 2000.

34. Zhao HL and Kim YS: Determination of the kinetic properties of platycodin $\mathrm{D}$ for the inhibition of pancreatic lipase using a 1,2-diglyceride-based colorimetric assay. Arch Pharm Res 27: 968-972, 2004.

35. Groop L: Bringing diabetes therapeutics to the big screen. Nat Biotechnol 21: 240-241, 2003.

36. Chen C, Grzegorzewski KJ, Barash S, et al: An integrated functional genomics screening program reveals a role for BMP-9 in glucose homeostasis. Nat Biotechnol 21: 294-301, 2003.

37. Kan NG, Junghans D and Izpisua Belmonte JC: Compensatory growth mechanisms regulated by BMP and FGF signaling mediate liver regeneration in zebrafish after partial hepatectomy. FASEB J 23: 3516-3525, 2009.

38. Sosa I, Cvijanovic O, Celic T, et al: Hepatoregenerative role of bone morphogenetic protein-9. Med Sci Monit 17: HY33-HY35, 2011.

39. Machinal-Quélin F, Dieudonné MN, Leneveu MC, Pecquery R and Giudicelli Y: Proadipogenic effect of leptin on rat preadipocytes in vitro: activation of MAPK and STAT3 signaling pathways. Am J Physiol Cell Physiol 282: C853-C863, 2002.

40. Stadler K, Jenei V, von Bölcsházy G, Somogyi A and Jakus J: Role of free radicals and reactive nitrogen species in the late complications of diabetes mellitus in rats. Orv Hetil 145: 1135-1140, 2004 (In Hungarian).

41. Caperuto LC, Anhê GF, Cambiaghi TD, et al: Modulation of bone morphogenetic protein-9 expression and processing by insulin, glucose, and glucocorticoids: possible candidate for hepatic insulin-sensitizing substance. Endocrinology 149: 6326-6335, 2008.

42. Xu XB, Leng XS, He ZP, et al: Inhibitory effect of retroviral vector containing anti-sense Smad4 gene on Ito cell line, LI90. Chin Med J (Engl) 117: 1170-1177, 2004. 